\title{
Comparison between Diastolic Subendocardial Tissue Pressures Measured Directly or Calculated from Pressure-Flow Relations
}

\author{
Jacques R. Rouleau, Bernard Cantin, John G. Kingma Jr* \\ Institut universitaire de cardiologie et de pneumologie de Québec-Université Laval 2725, Chemin Ste-Foy, \\ Ste-Foy (Quebec) Canada \\ Email: زjohn.kingma@fmed.ulaval.ca
}

How to cite this paper: Rouleau, J.R., Cantin, B. and Kingma Jr, J.G. (2017) Comparison between Diastolic Subendocardial Tissue Pressures Measured Directly or Calculated from Pressure-Flow Relations. World Journal of Cardiovascular Diseases, 7, 213-224.

https://doi.org/10.4236/wjcd.2017.77020

Received: June 7, 2017

Accepted: July 10, 2017

Published: July 13, 2017

Copyright $\odot 2017$ by authors and Scientific Research Publishing Inc. This work is licensed under the Creative Commons Attribution International License (CC BY 4.0).

http://creativecommons.org/licenses/by/4.0/

\begin{abstract}
Changes in intramyocardial tissue pressure modulate the relationship between coronary pressure and flow during the cardiac cycle. The present study compared the relation between measured and calculated diastolic subendocardial tissue pressure and coronary pressure at zero flow in anesthetized dogs after modulation of either coronary sinus (i.e. Fogarty catheter) or left ventricular intracavity (i.e. volume loading) pressure. Experiments were conducted in anesthetized, instrumented dogs; coronary pressure flow relations were constructed during pharmacologic vasodilatation and intramyocardial tissue pressure was measured using micromanometer pressure sensors. Elevated coronary sinus pressures did not affect subendocardial pressure-flow relations signifying that diastolic tissue pressure within this layer is the effective coronary back pressure. Higher left ventricular intracavity pressure did not affect either diastolic subendocardial tissue pressure or pressure flow relations within this layer. Results show a direct linear relation $\left(\mathrm{y}=1.106 \mathrm{x}-0.652 ; \mathrm{r}^{2}=\right.$ 0.59. $P=0.001$ ) between measured and calculated diastolic subendocardial tissue pressure and coronary pressure at zero-flow over a wide range of pressures after either LV systemic or coronary sinus pressure modulation. Knowledge of back pressure in the subendocardium is useful for the evaluation of efficacy of cardiac interventions on myocardial perfusion particularly at the level of the microcirculation.
\end{abstract}

\section{Keywords}

Intramyocardial Tissue Pressure, Pressure-Flow Relations, Transmural Myocardial Blood Flow, Microspheres, Coronary Sinus Pressure, Volume Overload 


\section{Introduction}

Changes in intramyocardial tissue pressure during the cardiac cycle can strongly affect the complex relationship between coronary pressure and flow. Bellamy initially reported that diastolic coronary blood flow can be stopped even if arterial perfusion pressure is superior to venous pressure [1]. Those studies, performed in conscious dogs, documented a positive coronary zero flow pressure (Pzf) intercept that exceeded venous pressure in the absence of coronary vascular smooth muscle tone; however, in the presence of intact tone Pzf is noticeably lower. The higher Pzf values during vasodilatation could be explained by either a Starling resistor effect within resistance vessels [1] [2] or a compliance effect of intramyocardial vessels [3]. Indeed, both hypotheses postulate that myocardial tissue pressure is partly responsible for genesis of Pzf.

The existence of tissue pressure gradients across the left ventricular wall during the cardiac cycle is well documented [4] [5] [6] [7]; intramyocardial pressure increases from subepicardium to subendocardium [6] [8] and during diastole is higher than intracavitary pressure [9]. Satoh et al. documented the marked dependence of intramyocardial tissue pressure on Pzf in transiently arrested canine hearts [10] [11]. These findings suggest that intramyocardial tissue pressure directly affects perfusion across the ventricular wall. When autoregulatory reserve is exhausted, diastolic subendocardial tissue pressure is believed to be the effective coronary back pressure, however, it must be greater than, or equal to, either left ventricular or coronary sinus pressure. During maximal pharmacologicallyinduced vasodilatation, the relation between coronary pressure and flow (PFR) is linear [12]. We already established in normal, in situ canine beating hearts that elevated coronary sinus pressure had no effect on subendocardial PFR; however at the same time the slope of the subepicardial PFR decreased [5]. These findings suggested that diastolic intramyocardial tissue pressure could be the effective back pressure in the subendocardium. As such, during diastole, subendocardial tissue pressure (measured with needle-tip transducers) and Pzf should be comparable; we therefore examined this hypothesis in the present study after modulations of either left ventricular chamber, or coronary sinus, pressures in anesthetized dogs.

\section{Material and Methods}

Adult ( 2 - 5 years of age) male mongrel dogs $(\mathrm{n}=19)$ weighing $20-25 \mathrm{~kg}$ were used for these studies; dogs were fed a standard diet and provided access to water ad libitum. Dogs were procured through the Service des Animaux de l'Université Laval. All animals received humane care in compliance with the Guide to the Care and Use of Experimental Animals (vols. 1 and 2) of the Canadian Council on Animal Care. Laval University is compliant with these guidelines (A5012-01); the Laval University Animal Ethics Committee approved these studies.

\subsection{Surgical Protocol}

Dogs were pre-medicated with diazepam (1 mg/kg, intravenous (IV); Sandoz 
Canada Inc., Boucherville, QC) and fentanyl citrate $(20 \mu \mathrm{g} / \mathrm{kg}$, IV; Sandoz Canada, Inc., Boucherville, QC) and subsequently anesthetized with $\alpha$-chloralose (100 mg/kg, IV; \#23120, Sigma-Aldrich Canada, Oakville, ON); a supplemental dose $(25 \mathrm{mg} / \mathrm{kg} / \mathrm{h}, \mathrm{IV})$ was administered to ensure anaesthesia. Following intubation, dogs were ventilated (Bird Mark 7 A respirator; Bird Corp., Calif.) with an air/ oxygen mixture to maintain blood gases within the physiological range. Catheters were positioned in the right and left femoral veins for saline infusions and withdrawal of blood samples. Via a midline abdominal incision, the spleen was removed to minimize adjustments in blood volume and hematocrit [13]; for the left ventricular (LV) pressure modulation experiments (i.e. Study B), $450 \mathrm{ml}$ of blood was collected over $30 \mathrm{~min}$ in a $1 \mathrm{~L}$ heparinized flask containing $200 \mathrm{ml}$ physiological saline. The abdominal cut-down was subsequently closed with surgical clips and a thermistor probe placed to measure abdominal temperature (maintained $\pm 38^{\circ} \mathrm{C}$ ).

The heart was exposed through a left thoracotomy (cf. Figure 1 experimental procedure); the pericardium was opened and the heart suspended in a pericardial cradle. A catheter was inserted into the internal thoracic artery for withdrawal of reference blood samples (for microsphere studies). A Pigtail (8F) catheter placed at the level of the aortic arch measured systemic pressure. A Fogarty catheter (balloon tip directed towards the ostium) was positioned in the coronary sinus to modulate coronary sinus pressure; in the LV cavity a Millar transducer (MPC 500) was positioned via the apex. The left main circumflex artery was dissected proximal to the first major marginal branch and a flow probe situated to measure phasic coronary blood flow (T206, Transonic Systems, New York, U.S.A.). A mechanical screw occluder was positioned just distal to the flow transducer to allow adjustments in coronary perfusion pressure. Arterial pressure just distal to the occluder was measured with a fluid-filled cannula introduced into the circumflex artery as previously described [14]; catheter patency was checked by venting to the atmosphere. Needle-tip transducers ( $5 \mathrm{Fr}, 1.7 \mathrm{~mm}$

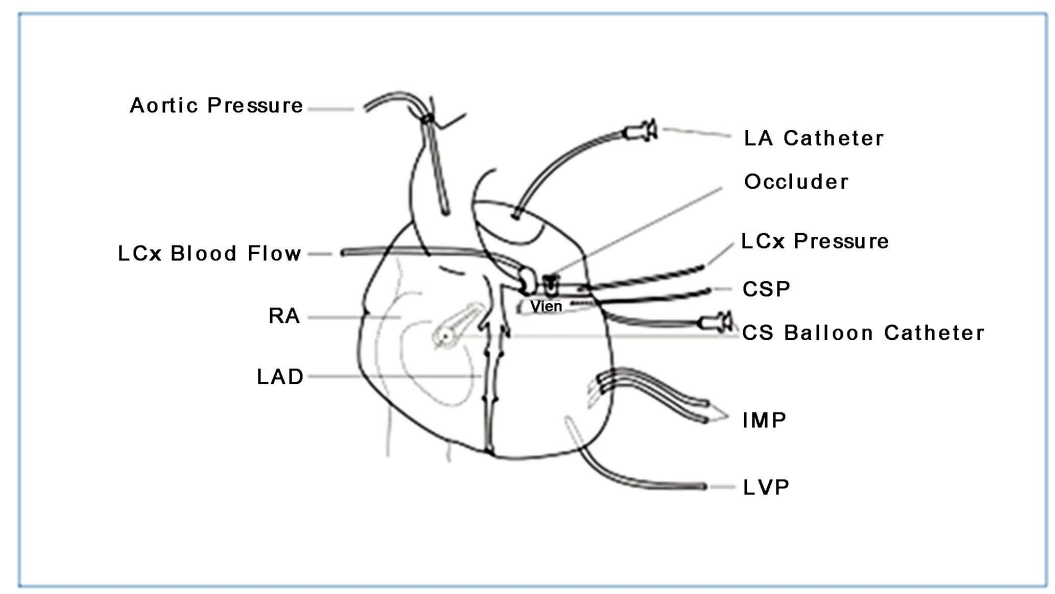

Figure 1. Schematic representation of surgical preparation. LA: left atrium; LCx: left circumflex artery; CSP: coronary sinus pressure; IMP: intramyocardial pressure; LVP: left ventricular pressure; RA: right atrium; LAD: left anterior descending artery. 
O.D., Millar Instruments, Houston, U.S.A.) were situated in subepicardium and subendocardium layers; sensors were oriented to face the endocardium [5] [7].

Left atrial, coronary artery and ascending aorta catheters were connected to Statham P23Db strain gauge manometers; zero was set at mid-chest level. Millar transducers were cross-calibrated with systolic aortic and diastolic left atrial pressures. Phasic coronary blood flow was measured using a volume flow-meter; all data were continuously recorded on a multi-channel recorder (Electronics for Medicine, Honeywell Instruments, Montréal, QC).

\subsection{Experimental Protocol}

Study A: For the coronary sinus pressure studies $(\mathrm{n}=7)$, diastolic pressure was increased in a range between $20-25 \mathrm{mmHg}$ by progressive inflation of the Fogarty balloon catheter. Fifteen minutes was allowed to reach steady state prior to data collection.

Study $B$ : For the LV intracavity pressure modulation studies $(\mathrm{n}=12)$, systemic pressure was increased in a range between $35-40 \mathrm{mmHg}$ by infusion of $350-400 \mathrm{ml}$ of blood into the left atrium (over 5-min). Fifteen minutes was allowed to reach steady state prior to data collection.

In studies $\mathrm{A}$ and $\mathrm{B}$, pressure-flow relations (PFR) were initially constructed under baseline conditions as previously described [15] [16] [17]; briefly, circumflex artery pressure was reduced in $5-10 \mathrm{mmHg}$ increments using the mechanical screw occluder. PFR were constructed during pharmacologic vasodilation produced by chromonar hydrochloride (Carbochromen, 8 mg/kgIV; \#7G2561, Roussel UCLAF S.A., FR) - supplemental doses were given as necessary $(2 \mathrm{mg} / \mathrm{kg}$, IV); this agent was used because it does not induce adverse systemic effects.

At the end of each experiment, a ligature was tied around the circumflex artery distal to the micrometric occluder and India ink was injected to permit delineation of the posterior perfusion bed. Under deep anesthesia, the heart was arrested (in diastole) by intra-atrial injection of saturated $\mathrm{KCl}$; the heart was extirpated, washed and fixed by immersion in $10 \%(\mathrm{v} / \mathrm{v})$ neutral formalin (SigmaAldrich Canada, Oakville, ON).

\subsection{Calculations and Data Analysis}

The atria, ventricles and interventricular septum were sectioned and blood flow analyzed as previously described [18] [19]. Myocardial oxygen consumption $\left(\mathrm{MVO}_{2} ; \mathrm{ml} / \mathrm{min} / 100 \mathrm{~g}\right)$ was calculated as the product of total myocardial blood flow (microspheres) and the artero-coronary sinus oxygen content difference. Hemodynamic data were compared using ANOVA; $P$-value of 0.05 was considered statistically significant. For each dog, diastolic circumflex artery pressure (Y axis; $\mathrm{mmHg}$ ) was plotted against subendocardial blood flow (X axis; $\mathrm{ml} / \mathrm{min}$ / $100 \mathrm{~g})$ to construct subendocardial PFR [12] [20] using a minimum of three pressure-flow data points; using a linear regression model the Pzf was calculated (i.e. the intercept on the $\mathrm{Y}$-axis). Data from all dogs were pooled and a correlation between Pzf and diastolic subendocardial tissue pressure determined using a 
linear regression model. To analyse PFR in subendocardium and LV posterior wall, myocardial blood flow (microspheres) was plotted against diastolic circumflex artery pressure. The slope of the regression lines were calculated by fitting the data to a simple linear regression model; Pzf was determined. The PFR and $\mathrm{PzF}$ were determined for each $\operatorname{dog}$ and for the pooled data and values were compared between control and high coronary sinus or LV pressures. The correlation coefficient was determined for each regression and differences between slope and intercepts on the pressure axis were tested using ANOVA. The 95\% confidence interval for each regression was also estimated as previously described [5]. All statistical analyses were done using the SAS General Linear Model and Correlation procedures [21].

\section{Results}

\subsection{Study A: Coronary Sinus Modulation}

Hemodynamic changes during coronary sinus pressure elevation are summarized in Table 1; as expected coronary sinus systolic and diastolic pressures increased; diastolic pressure in the epicardial tissue layer increased markedly but subendocardial tissue pressure was unaffected. All other hemodynamic variables such as heart rate and LV pressure were stable. In addition, diastolic coronary artery pressure and myocardial oxygen consumption were comparable to control conditions.

Higher coronary sinus pressures resulted in a downward shift of the total myocardial PFR (vs. baseline) with no effect on the subendocardial layer PFR as shown in Figure 2. The absence of change in subendocardial layer PFR suggests

Table 1. Summary of hemodynamic changes.

\begin{tabular}{lccccccccc}
\hline & $\mathrm{HR}$ & $\mathrm{LV}_{\mathrm{s}}$ & $\mathrm{LV}_{\mathrm{d}}$ & $\mathrm{PC}_{\mathrm{d}}$ & $\mathrm{CS}_{\mathrm{s}}$ & $\mathrm{CS}_{\mathrm{d}}$ & $\mathrm{ENDO}_{\mathrm{d}}$ & $\mathrm{EPI}_{\mathrm{d}}$ & $\mathrm{MVO}_{2}$ \\
\hline Control & $156 \pm 18$ & $125 \pm 11$ & $5 \pm 3$ & $54 \pm 13$ & $21 \pm 10$ & $8 \pm 3$ & $19 \pm 5$ & $32 \pm 7$ & $12 \pm 5$ \\
High & $154 \pm 23$ & $123 \pm 9$ & $4 \pm 3$ & $60 \pm 14$ & $89 \pm 16$ & $26 \pm 3$ & $21 \pm 7$ & $45 \pm 13$ & $12 \pm 5$ \\
$\boldsymbol{P}$ (Sinus) & $\mathrm{NS}$ & $\mathrm{NS}$ & $\mathrm{NS}$ & $\mathrm{NS}$ & 0.001 & 0.001 & $\mathrm{NS}$ & 0.001 & $\mathrm{NS}$ \\
\hline & & & & $L V$ & & & & & \\
\hline Control & $174 \pm 34$ & $106 \pm 8$ & $4 \pm 4$ & $40 \pm 13$ & $9 \pm 3$ & $4 \pm 3$ & $12 \pm 3$ & $20 \pm 5$ & $7 \pm 2$ \\
High & $142 \pm 46$ & $145 \pm 12$ & $10 \pm 7$ & $57 \pm 20$ & $13 \pm 6$ & $7 \pm 4$ & $20 \pm 11$ & $31 \pm 6$ & $11 \pm 6$ \\
$P$ (LV) & 0.008 & 0.001 & 0.001 & 0.001 & 0.003 & 0.018 & 0.001 & 0.001 & 0.013 \\
$\boldsymbol{P}$ (Sinus vs LV) & $\mathrm{NS}$ & $\mathrm{NS}$ & 0.012 & 0.002 & 0.001 & 0.001 & 0.005 & 0.001 & 0.003 \\
$\boldsymbol{P}$ (Control vs & 0.019 & 0.001 & 0.002 & 0.001 & 0.001 & 0.001 & 0.001 & 0.001 & $\mathrm{NS}$ \\
High) & & & & & & & & \\
$P$ (Interaction) & 0.034 & 0.001 & 0.006 & 0.028 & 0.001 & 0.001 & 0.045 & $\mathrm{NS}$ & $\mathrm{NS}$ \\
\hline
\end{tabular}

Data are means $\pm 1 S D$. Sinus, LV: coronary sinus or LV pressure modulation; HR: heart rate (beats/min); $\mathrm{LV}_{\mathrm{s}}, \mathrm{LV}_{\mathrm{d}}$ : systolic, diastolic left ventricular pressure $(\mathrm{mmHg}) ; \mathrm{PC}_{\mathrm{d}}$ : diastolic coronary artery pressure $(\mathrm{mmHg}) ; \mathrm{CS}_{\mathrm{s}}, \mathrm{CS}_{\mathrm{d}}$ : systolic, diastolic coronary sinus pressure $(\mathrm{mmHg}) ; \mathrm{ENDO}_{\mathrm{d}}, \mathrm{EPI}_{\mathrm{d}}$ : diastolic endocardial, epicardial tissue pressure $(\mathrm{mmHg}) ; \mathrm{MVO}_{2}$ : myocardial oxygen consumption $(\mathrm{ml} / \mathrm{min} / 100 \mathrm{~g}) . P$ value using ANOVA with df of 3,89 , NS: not significant. 


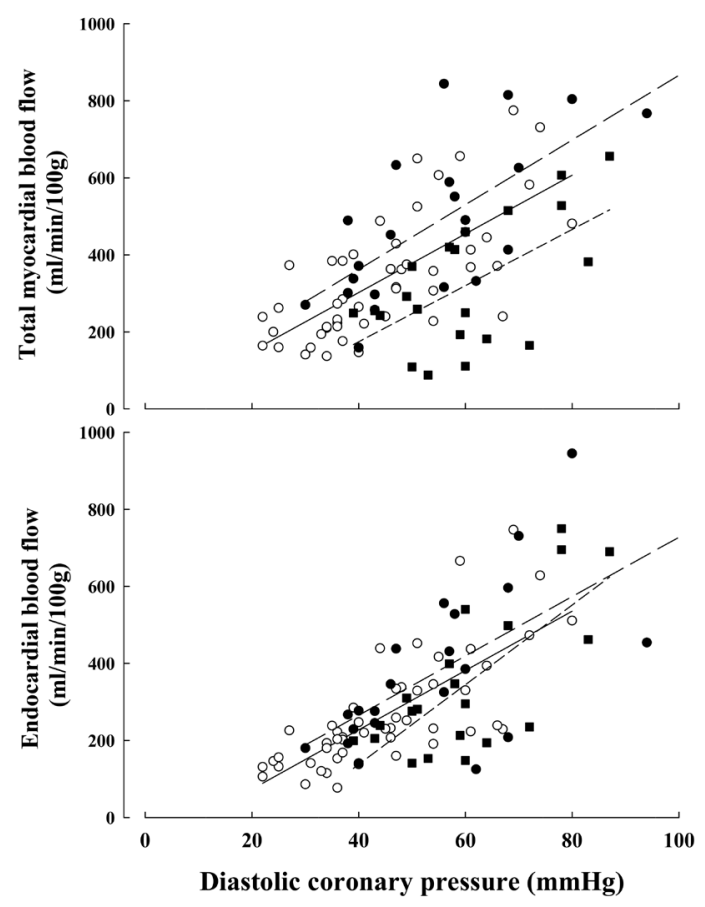

Figure 2. Upper panel: relation between diastolic coronary pressure and total myocardial blood flow (measured with microspheres) in the posterior ventricular wall under control (solid line and open circles; $\mathrm{y}=7.61 \mathrm{x}-0.26, \mathrm{r}^{2}=0.49$ ), elevated coronary sinus pressure (long-dashed line and closed squares; $y=7.29 x-117.24, r^{2}=0.35$ ) and elevated LV intracavity pressure (short-dashed line and closed circles, $\left.y=8.40 x-26.56, r^{2}=0.57\right)$. Lower panel: relation between diastolic coronary pressure and subendocardial layer blood flow in the posterior ventricular wall under control (solid line and open circles; $\mathrm{y}=7.70 \mathrm{x}-80.74, \mathrm{r}^{2}=0.56$ ), elevated coronary sinus pressure (long-dashed line and closed squares; $\mathrm{y}=10.34 \mathrm{x}-275.89, \mathrm{r}^{2}=0.53$ ) and elevated LV intracavity pressure (short-dashed line and closed circles, $\left.\mathrm{y}=7.71 \mathrm{x}-43.00, \mathrm{r}^{2}=0.49\right)$.

that diastolic tissue pressure in this layer must be greater than, or equal to coronary sinus pressure. Consequently, diastolic subendocardial tissue pressure appears to be the effective coronary back pressure. In Figure 3, we show that under either control or increased coronary sinus pressure conditions that the correlation between calculated subendocardial Pzf and diastolic subendocardial tissue pressure is linear.

\subsection{Study B: LV Intracavity Pressure Modulation}

Hemodynamic changes during LV loading are reported in Table 1. Marked increase of LV and diastolic coronary artery pressure occurred as expected; significant changes were observed for heart rate (decreased) and systolic/diastolic coronary sinus pressure (increased). Diastolic tissue pressure in both subendocardial and epicardial layers increased as did myocardial oxygen consumption. The correlation between calculated subendocardial Pzf and diastolic 


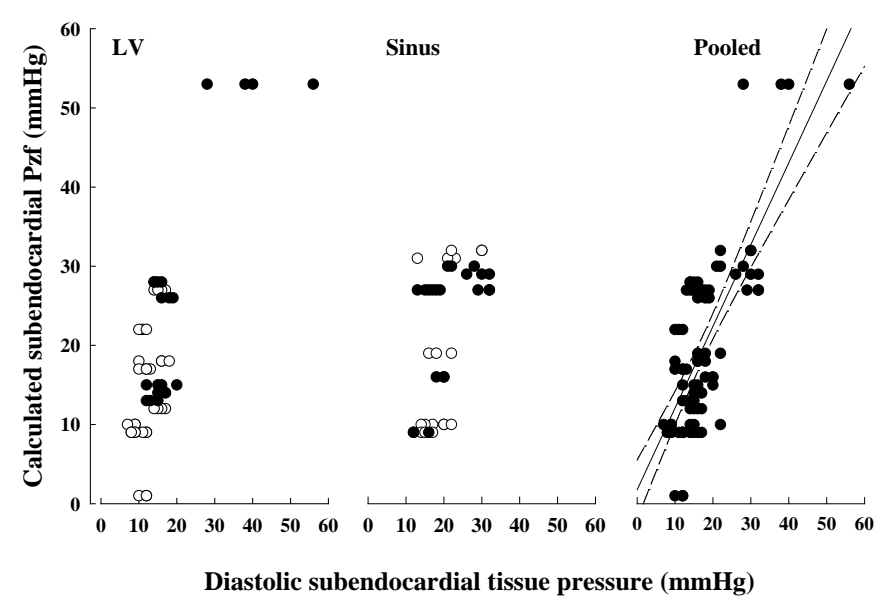

Figure 3. Relation between measured diastolic subendocardial tissue pressure $(\mathrm{mmHg})$ and calculated subendocardial pressure at zero flow $(\mathrm{mmHg}$ ) during elevation of coronary sinus pressure (left panel), increased LV intracavity pressure (middle panel) and pooled data (right panel, $\mathrm{y}=1.02 \mathrm{x}+1.94 ; \mathrm{r}^{2}=0.53$ ).

subendocardial tissue pressure was also linear during either baseline or higher LV intracavity pressure conditions (cf. Figure 2).

All data from both studies were pooled since no discernible difference was observed after comparing the relation between measured and calculated subendocardial tissue pressure at zero flow for both interventions; the slope or intercept of the relation between calculated subendocardial Pzf and diastolic subendocardial tissue pressure $\left(\mathrm{y}=1.106 \mathrm{x}-0.652 ; \mathrm{r}^{2}=0.59\right)$ did not differ from the line of identity $(P=0.89)$.

\section{Discussion}

Results of the present study document a direct correlation between measured and calculated diastolic subendocardial tissue pressure and Pzf over a wide range of pressures. This relationship has previously been examined in an experimental model of prolonged diastole [22]; results showed that blood flow is abolished when tissue pressure in the subepicardial tissue layer and coronary artery pressure are equal. However, closing pressures in the subendocardial layer and blood flow were not evaluated in that study. It has been established that the subendocardial tissue layer is at greater risk of injury in the setting of cardiovascular disease and is due, in part, to alterations in blood flow at the level of the microcirculation [23] [24].

Regulation and modulation of myocardial blood flow is not uniform across the various levels of the vascular tree [25] [26]. Under normal conditions in vessels with tone, almost 25 percent of coronary vascular resistance is controlled by coronary arterioles; however, during vasodilatation, resistance is redistributed to larger arteries and veins. As such, larger microvessels (compared to small arterioles) are less involved in regulation of transmural blood perfusion under normal conditions. However; during arteriolar vasodilatation arteriolar resistance de- 
creases which ultimately contributes to greater total coronary vascular resistance [27]. Since distribution of vascular resistance is primarily located between arteries and arterioles, the added element of transmural heterogeneity between subepicardium and subendocardium must also be considered. The distribution of microvascular resistances and pressures differs within subendocardial and subepicardial microcirculations during maximal vasodilatation [28].

Myocardial tissue pressure [6], ventricular loading conditions [14] [29], pericardial pressure [30], as well as arterial inflow and coronary sinus outflow pressures [1] [5] [19] [31] all affect microvascular blood flow across the LV wall. In addition, cardiac contraction affects myocardial vessels; as a result, arterial inflow to myocardium occurs principally during diastole [5] [32] [33]. Modulation of intramyocardial tissue pressure across the ventricular wall has been reported during systole [32]; the relative balance between intramyocardial and intravascular pressure is assumed to be constant within subendocardium and midmyocardium. On the other hand, the diameter of midmyocardial venules is constant from end-diastole to end-systole, however, the diameter of subepicardial and subendocardial venules varies [34]. Forward and backward movement of intramyocardial blood within coronary capacitance vessels (i.e. coronary slosh) also occurs during contraction; during systole, intramyocardial blood translocates from deeper to superficial myocardial layers [35] [36]. Physiopathological changes within intramyocardial vessels also induce profound changes in blood perfusion within the deeper myocardial layers [37].

Various methodological limitations of these studies merit consideration. First of all, back pressure in the subendocardium corresponds to tissue pressure that is equal or greater than coronary venous pressure [5]. Overestimation of Pzf is possible particularly when it is extrapolated from a linear regression due to concavity (due to presence of collateral blood flow [38]) of the pressure-flow curve as it approaches the blood flow axis (i.e. y-axis) at low coronary perfusion pressures [38] [39]. However, when mean coronary perfusion pressure is maintained above $40 \mathrm{mmHg}$, as in the present study, the influence of collateral blood flow is minimized due to the fact that perfusion pressure is higher than that necessary for recruitment of collateral vessels and induction of myocardial ischemia. Secondly, the selected experimental model accounted for most factors that modulate myocardial perfusion with the exception of coronary sinus and LV intracavity pressure. Thirdly, experiments were performed during pharmacologic vasodilatation to minimize potential coronary artery capacitance effects [19]. Finally, potential problems related to measurement of intramyocardial tissue pressures are known; for instance, tissue damage and oedema may occur during placement of sensors [40]. However, we [41], and others [10] [42] [43], have reported that micromanometric pressure sensors are sufficiently sensitive to measure changes in intramyocardial tissue pressure under different experimental conditions. Positioning (i.e. tissue depth) and direction of each sensor was verified post-mortem.

In summary, findings of this study show a linear relation between measured 
and calculated diastolic subendocardial tissue pressures and Pzf over a wide range of myocardial tissue pressures. This information is useful to evaluate the efficacy of different cardiac interventions on myocardial blood flow distribution, particularly at the level of the microcirculation, since subendocardial tissue pressure greater than or equal to coronary sinus or LV diastolic cavity pressure must be used as back pressure for the calculation of vascular resistance. Knowledge of coronary back pressure in the clinical setting or in experimental models of cardiac pathology might help to determine optimal treatment strategy for preservation of myocardial blood flow and tissue viability.

\section{Acknowledgements}

An operating grant from the Heart and Stroke Foundation of Quebec provided funding for these studies.

\section{References}

[1] Bellamy, R.F. (1978) Diastolic Coronary Artery Pressure-Flow Relations in the Dog. Circulation Research, 43, 92-101. https://doi.org/10.1161/01.RES.43.1.92

[2] Permutt, S. and Riley, R.L. (1963) Hemodynamics of Collapsible Vessels with Tone: The Vascular Waterfall. The Journal of Applied Physiology, 18, 924-932.

[3] Spaan, J.A. (1985) Coronary Diastolic Pressure-Flow Relation and Zero Flow Pressure Explained on the Basis of Intramyocardial Compliance. Circulation Research, 56, 293-309. https://doi.org/10.1161/01.RES.56.3.293

[4] Downey, J.M. and Kirk, E.S. (1974) Distribution of Coronary Blood Flow across the Canine Heart Wall during Systole. Circulation Research, 34, 251-257. https://doi.org/10.1161/01.RES.34.2.251

[5] Cantin, B. and Rouleau, J.R. (1992) Myocardial Tissue Pressure and Blood Flow during Coronary Sinus Pressure Modulation in Anesthetized Dogs. The Journal of Applied Physiology, 73, 2184-2191.

[6] Stein, P.D., Sabbah, H.N., Marzelli, M. and Blick, E.F. (1980) Comparison of the Distribution of Intramyocardial Pressure across the Canine Left Ventricular Wall in the Beating Heart during Diastole and in the Arrested Heart. Circulation Research, 47, 258-267. https://doi.org/10.1161/01.RES.47.2.258

[7] Stein, P.D., Marzilli, M., Sabbah, H.N. and Lee, T. (1980) Systolic and Diastolic Pressure Gradients within the Left Ventricular Wall. Journal of Physiology-Heart and Circulatory Physiology, 238, H625-H630.

[8] Sabbah, H.N. and Stein, P.D. (1982) Effect of Acute Regional Ischemia on Pressure in the Subepicardium and Subendocardium. Journal of Physiology-Heart and Circulatory Physiology, 242, H240-H244.

[9] Westerhof, N., Boer, C., Lamberts, R.R. and Sipkema, P. (2006) Cross-Talk between Cardiac Muscle and Coronary Vasculature. Physiological Reviews, 86, 1263-1308. https://doi.org/10.1152/physrev.00029.2005

[10] Satoh, S., Maruyama, Y., Watanabe, J., Keitoku, M., Hangai, K. and Takishima, T. (1990) Coronary Zero Flow Pressure and Intramyocardial Pressure in Transiently Arrested Heart. Cardiovascular Research, 24, 358-363. https://doi.org/10.1093/cvr/24.5.358

[11] Satoh, S., Watanabe, J., Keitoku, M., Itoh, N., Maruyama, Y. and Takishima, T. (1988) Influences of Pressure Surrounding the Heart and Intracardiac Pressure on 
the Diastolic Coronary Pressure-Flow Relation in Excised Canine Heart. Circulation Research, 63, 788-797. https://doi.org/10.1161/01.RES.63.4.788

[12] Rouleau, J., Boerboom, L.E., Surjadhana, A. and Hoffman, J.I. (1979) The Role of Autoregulation and Tissue Diastolic Pressures in the Transmural Distribution of Left Ventricular Blood Flow in Anesthetized Dogs. Circulation Research, 45, 804815. https://doi.org/10.1161/01.RES.45.6.804

[13] Sato, N., Shen, Y.-T., Kiuchi, K., Shannon, R.P. and Vatner, S.F. (1995) Splenic Contraction-Induced Increases in Arterial $\mathrm{O}_{2}$ Reduce Requirement for CBF in Conscious Dogs. American Journal of Physiology, 269, H491-H503.

[14] Rouleau, J.R., Simard, D. and Kingma Jr., J.G. (1999) Myocardial Blood Flow Regulation Relative to Left Ventricle Pressure and Volume in Anesthetized Dogs. Canadian Journal of Physiology and Pharmacology, 77, 902-908.

https://doi.org/10.1139/y99-100

[15] Rouleau, J.R., Simard, D. and Kingma, J.G. (2000) Effect of Angiotensin Inhibition on the Coronary Artery Lower Pressure Limit in Anesthetized Dogs. Canadian Journal of Physiology and Pharmacology, 78, 892-896. https://doi.org/10.1139/y00-071

[16] Canty, J.M.J. (1988) Coronary Pressure-Function and Steady-State Pressure-Flow Relations during Autoregulation in the Unanesthetized Dog. Circulation Research, 63, 821-836. https://doi.org/10.1161/01.RES.63.4.821

[17] Klocke, F.J., Ellis, A.K. and Canty Jr., J.M. (1987) Interpretation of Changes in Coronary Flow That Accompany Pharmacologic Interventions. Circulation, 75, V34V38.

[18] Rouleau, J.R., Simard, D., Blouin, A. and Kingma Jr., J.G. (2002) Angiotensin Inhibition and Coronary Autoregulation in a Canine Model of LV Hypertrohy. Basic Research in Cardiology, 97, 384-391. https://doi.org/10.1007/s003950200047

[19] Rouleau, J.R. and White, M. (1985) Effects of Coronary Sinus Pressure Elevation on Coronary Blood Flow Distribution in Dogs with Normal Preload. Canadian Journal of Physiology and Pharmacology, 63, 787-797. https://doi.org/10.1139/y85-131

[20] Baird, R.J. and Adiseshiah, M. (1976) The Response of Diastolic Myocardial Tissue Pressure and Regional Coronary Blood Flow to Increased Preload from Blood, Colloid and Crystalloids. Surgery, 79, 644-651.

[21] Spector, P.C., Goodnight, J.H., Sall, J.P. and Sarle, W.S. (1985) The GLM Procedure. In: SAS User's Guide: Statistics, 5th Edition, SAS Institute Inc., Cary, NC, 433-507.

[22] Sabbah, H.N., Marzilli, M., Liu, Z.-Q. and Stein, P.D. (1986) Relation of Intramyocardial Pressure to Coronary Pressure at Zero Flow. Clinical and Experimental Pharmacology and Physiology, 13, 477-486. https://doi.org/10.1111/j.1440-1681.1986.tb00928.x

[23] Hoffman, J.I.E. (1981) Why Is Myocardial Ischemia so Commonly Subendocardial? Clinical Science, 61, 657-662. https://doi.org/10.1042/cs0610657

[24] Hoffman, J.I.E. (1987) Transmural Myocardial Perfusion. Progress in Cardiovascular Diseases, 29, 429-464. https://doi.org/10.1016/0033-0620(87)90016-8

[25] Kanatsuka, H., Lamping, K.G., Eastham, C.L. and Marcus, M.L. (1990) Heterogeneous Changes in Epimyocardial Microvascular Size during Graded Coronary Stenosis. Circulation Research, 66, 389-396. https://doi.org/10.1161/01.RES.66.2.389

[26] Lamping, K.G., Kanatsuka, H., Eastham, C.L., Chilian, W.M. and Marcus, M.L. (1989) Nonuniform Vasomotor Responses of the Coronary Microcirculation to Serotonin and Vasopressin. Circulation Research, 65, 343-351.

https://doi.org/10.1161/01.RES.65.2.343 
[27] DeFily, D.V. and Chilian, W.M. (1995) Coronary Microcirculation: Autoregulation and Metabolic Control. Basic Research in Cardiology, 90, 112-118. https://doi.org/10.1007/BF00789441

[28] Chilian, W.M. (1991) Microvascular Pressures and Resistances in the Left Ventricular Subepicardium and Subendocardium. Circulation Research, 69, 561-570. https://doi.org/10.1161/01.RES.69.3.561

[29] Ellis, A.K. and Klocke, F.J. (1979) Effects of Preload on the Transmural Distribution of Perfusion and Pressure-Flow Relationships in the Canine Coronary Vascular Bed. Circulation Research, 46, 68-77. https://doi.org/10.1161/01.RES.46.1.68

[30] Kingma Jr., J.G., Martin, J. and Rouleau, J.R. (1994) Acute Tamponade Alters Subendo- and Subepicardial Pressure-Flow Relations Differently during Vasodilation. American Journal of Physiology, 267, H133-H138.

[31] Bellamy, R.F., Lowessohn, H.S., Ehrlich, W. and Baer, R.W. (1980) Effect of Coronary Sinus Occlusion on Coronary Pressure-Flow Relations. American Journal of Physiology, 239, H57-H64.

[32] Kajiya, F., Yada, T., Matsumoto, T., Goto, M. and Ogasawara, Y. (2000) Intramyocardial Influences on Blood Flow Distributions in the Myocardial Wall. Annals of Biomedical Engineering, 28, 897-902. https://doi.org/10.1114/1.1308487

[33] Dieudonne, J.M. (1967) Tissue-Cavitary Difference Pressure of Dog Myocardium under Stress. American Journal of Physiology, 213, H107-H111.

[34] Hoffman, J.I. (1995) Heterogeneity of Myocardial Blood Flow. Basic Research in Cardiology, 90, 103-111. https://doi.org/10.1007/BF00789440

[35] Austin, R.E.J., Smedira, N.G., Squiers, T.M. and Hoffman, J.I.E. (1994) Influence of Cardiac Contraction and Coronary Vasomotor Tone on Regional Myocardial Blood Flow. American Journal of Physiology 266, H2542-H2553.

[36] Flynn, A.E., Coggins, D.L., Goto, M., Aldea, G.S., Austin, R.E., Doucette, J.W., et al. (1992) Does Systolic Subepicardial Perfusion Come from Retrograde Subendocardial Flow? American Journal of Physiology, 262, H1759-H1769.

[37] Morita, K., Mori, H., Tsujioka, K., Kimura, A., Ogasawara, Y., Goto, M., et al. (1997) $\alpha$-Adrenergic Vasoconstriction Reduces Systolic Retrograde Coronary Blood Flow. American Journal of Physiology, 273, H2746-H2755.

[38] Messina, L.M., Hanley, F.L., Uhlig, P.N., Baer, R.W., Grattan, M.T. and Hoffman, J.I.E. (1985) Effects of Pressure Gradients between Branches of the Left Coronary Artery on the Pressure Axis Intercept and the Shape of Steady State Circumflex Pressure-Flow Relations in Dogs. Circulation Research, 56, 11-19. https://doi.org/10.1161/01.RES.56.1.11

[39] Klocke, F.J., Weinstein, I.R., Klocke, J.F., Ellis, A.K., Kraus, D.R., Mates, R.E., et al. (1981) Zero-Flow Pressures and Pressure-Flow Relationships during Long Diastoles in the Canine Coronary Bed before and during Maximum Vasodilatation: Limited Influence of Capacitive Effects. The Journal of Clinical Investigation, 68, 970-980. https://doi.org/10.1172/JCI110351

[40] Rabbany, S.Y., Kresh, J.Y. and Noordergraaf, A. (1989) Intramyocardial Pressure: Interaction of Myocardial Fluid Pressure and Fiber Stress. American Journal of Physiology, 257, H357-H364.

[41] Kingma Jr., J.G., Armour, J.A. and Rouleau, J.R. (1996) Left Ventricular Intramyocardial Pressure Determination Using Two Different Solid-State Micromanometric Pressure Sensors. Canadian Journal of Physiology and Pharmacology, 74, 701-705. https://doi.org/10.1139/y96-068

[42] Denys, B.G., Aubert, A.E., Ector, H., Kesteloot, H. and DeGeest, H. (1985) Intra- 
myocardial Pressure in Canine Heart. The Journal of Thoracic and Cardiovascular Surgery, 90, 888-895.

[43] Ido, A., Hasebe, N., Matsuhashi, H. and Kikuchi, K. (2001) Coronary Sinus Occlusion Enhances Coronary Collateral Flow and Reduces Subendocardial Ischemia. American Journal of Physiology, 280, H1361-H1367.

\section{Scientific Research Publishing}

Submit or recommend next manuscript to SCIRP and we will provide best service for you:

Accepting pre-submission inquiries through Email, Facebook, LinkedIn, Twitter, etc. A wide selection of journals (inclusive of 9 subjects, more than 200 journals)

Providing 24-hour high-quality service

User-friendly online submission system

Fair and swift peer-review system

Efficient typesetting and proofreading procedure

Display of the result of downloads and visits, as well as the number of cited articles Maximum dissemination of your research work

Submit your manuscript at: http://papersubmission.scirp.org/

Or contact wjcd@scirp.org 